Journal of Social Sciences (COES\&RJ-JSS)

ISSN (E): 2305-9249 ISSN (P): 2305-9494

Publisher: Centre of Excellence for Scientific \& Research Journalism, COES\&RJ LLC

Online Publication Date: $1^{\text {st }}$ April 2017

Online Issue: Volume 6, Number 2, April 2017

http://centreofexcellence.net/J/JSS/JSS\%20Mainpage.htm

\title{
Evaluation of Teacher Professionalism Development Policy through Teachers Working Group program: Policy Assessment Study on Teacher Working Group of Cluster 1 and Cluster 4 in Blimbing, Malang, East Java, Indonesia. \\ Harun Al Rashid \\ Candidate of Doctor in Non-Formal Education, State University of Malang, Malang, East Java, Indonesia \\ Supriyono \\ Professor, Department of Non-formal Education, State University of Malang, Malang, East Java, Indonesia \\ Djauzi Moedzakir \\ Associate Professor, Department of Non-formal Education, State University of Malang, Malang, East Java, Indonesia \\ Muhadjir Efendi \\ Professor, Department of Non-formal Education, State University of Malang, Malang, East Java Indonesia
}

Abstract:

This study aimed at describing the effectiveness of: (1) the context of Teachers Working Group program viewed from the relevance between the goals and objectives of its program to the needs and problems of increasing the teachers' professionalism; (2) input (feed-back) of Teachers Working Group program from the conformity of participating teachers characteristics, work programs, and its organizational capabilities in achieving program objectives based on the development standards; (3) the process of Teachers Working Group program implementation from the compatibility of tutor performance, member activity, infra-structure utilization, and its performance management based on the development standard; and (4) the effectiveness of Teachers Working Group program for improving the participating teachers' professionalism and their attitudes toward the program. This is an evaluational research by which the model included evaluation of Context, Input, Process, and Product (CIPP) developed by Stuffle beam. The study was conducted in Cluster 1 and Cluster 4 of the Teachers Working Group in Blimbing, Malang, East Java, Indonesia, in January-April 2016. The informants were members of the board and some participating teachers, and coaches in both clusters. Data were collected by observation, interview, and documentation. The data were analyzed by using Yin model consisting of five stages, namely compiling, disassembling, reassembling, interpreting, and concluding. The findings indicated that (1) the relevance between the goals and objectives of the program to the needs and problems of teachers' professionalism improvement and the Teachers Working Group context in both groups were sufficiently effective to achieve the program objectives. The component of cluster 1 context was more effective than that of cluster 4 . The objectives, the needs of teachers, and work programs of group 1 were more relevant than those of group 4; (2) In terms of the teachers' interest to program and teachers' needs of learning management, training programs, and capabilities of tutors and administrators in both groups, the input component of cluster 1 was quite effective, while cluster 4 was less effective; (3) In terms of compatibility of tutor performance, member activity, infrastructure utilization, and the group management performance, the program implementation in both groups were equally effective; and (4) In terms of the benefits of the program for the improvement of teacher

This work is licensed under a Creative Commons Attribution 4.0 International License. 
Journal of Social Sciences (COES\&RJ-JSS), 6(2), pp. 300-318

is professionalism and teacher is positive attitude towards the program in both groups, the implementation of the program in both groups was classified quite effective.

Keywords:

Policy Evaluation, Teacher Professional Development, Teachers Working Group

Citation:

Rashid, Harun Al; Supriyono; Moedzakir, Djauzi; Efendi, Muhadjir (2017); Evaluation of Teacher Professionalism Development Policy through Teachers Working Group program: Policy Assessment Study on Teacher Working Group of Cluster 1 and Cluster 4 in Blimbing, Malang, East Java, Indonesia; Journal of Social Sciences (COES\&RJ-JSS), Vol.6, No.2, pp: 300-318. 


\section{Introduction}

Teachers as educators play a strategic role in national development and as a central actor directly related to educational success. Brandt (1993) (Jalal and Supriya, 2001) explained that teachers are keys to improve the quality of education and are in the central point of any education reform efforts aimed at qualitative changes. Any attempt to improve the quality of education, such as curriculum renewal, development of teaching methods, provision of facilities and infrastructure, will be meaningful only if it involves teachers.

Teachers of Elementary School as pioneers in the success of institution goals should keep abreast of the times as the society needs of education also continues to change. Therefore, teachers should be able to align their knowledge with the demands of the times. By possessing up to date knowledge, teachers will be able to make their students learn harmoniously with the demands of the times. The constantly flowing science and technology developments is a serious concern for the government that teachers shall be also given professional development on an ongoing basis so that they do not miss the latest developments in science and technology.

Teachers' professional development should be generated from real needs or problems they face. One forum to improve elementary school teachers' professionalism is Teachers Working Group. Teachers Working Group is a non-structural school organization that is independent, family based, and non-hierarchical relationships with other institutions. Teachers Working Group facilitate activities of professional teachers, both classroom and subject teachers. This group is called Kelompok Kerja Guru (KKG) in Indonesian.

According to KKG standard development (MONE, 2008: 4-5), the purpose of KKG are: (1) broadening teachers' awareness and knowledge in various ways, particularly the mastery of the substance of learning materials, syllabus, preparation of learning materials, learning strategies, teaching methods, maximizing the use of facilities/infrastructure to learn, utilizing learning resources, and so forth; (2) providing an opportunity for members of working groups or working meetings to share experiences and providing mutual support and feedback; (3) improving knowledge and skills, as well as adopting a reform approach in a more professional learning for the participants of working groups or working meetings; (4) empowering and assisting members of the working group in carrying out learning tasks at school; (5) changing work culture of working group members or consultation work (increasing knowledge, competence and performance) and developing teachers professionalism through professional development activities at KKG level; (6) improving the quality of education and the learning process reflected in improved students' learning outcomes; and (7) improving teachers' competence through activities at KKG level.

In teachers coaching and professional training through $\mathrm{KKG}$, the learning system is selflearning which according to Apps (1979) (in Faisal, 2002) referred to as adult education process. In non-formal Education (PLS) adult education is carried out by providing unorganized learning opportunities. Independent learning is a way of learning that requires a person to learn on their own initiative in studying learning materials, tasks, strengthen skills in applying his experience in the field or occupation (Open University, 2014: 1). Independent learning, in addition to initiative, motivation, and self-willingness, independent learning can be carried out through group study, following tutorial by direct 
meeting or media, such as utilizing library, following radio and television broadcasts as well as using other learning resources.

The data of preliminary observations on the KKG cluster 1 and 4 Blimbing sub-district; Malang indicated that the two groups of KKG have had an annual work program and activities schedule. The work program was developed with some teachers' suggestions. The implementation of the activities was carried out on Saturday after effective school hours in members' house in turn. Program evaluation that has been carried out is evaluation process, which is matching the activity plan and the realization. Evaluation result was carried out based on principal report and teachers' achievement in following exemplary teacher competitions. The dominant obstacle lies in the lack of funds to bring in resource persons from outside, comparative studies, as well as for the procurement of laboratory facilities for practical learning as a learning innovation cluster teacher members.

In addition to funding, the obstacle faced is teachers' low participation in following KKG, especially senior teachers. There are two teachers needs that have not been accommodated in the two groups: the need to have coaching in Credit Scoring Assessment (PAK) and coaching in writing Scientific Writing (KTI), particularly Action Research (PTK).

The initial findings should be followed - up, has the KKG work program in both groups been based on the real needs of all teachers to improve their professionalism? How to find the teachers' needs? Has the evaluation process as set forth carried out correctly? Why is the evaluation result only carried out based on principal's report? Is it true that fund becomes the obstacle of program implementation, particularly to invite resource, comparative study, as well as to create a learning laboratory? How did they get their funds so far? Why coaching for classroom action research needed by the majority of teacher members of the group has not been conducted? Despite having administrators resources and adequate tutors, why group 1 lagged behind group 4 in cooperation with parties outside KKG? This is why evaluation research of KKG program policy in both groups.

\section{Research purposes}

This study aims to describe the effectiveness of: (1) the context of KKG program viewed from the relevance of the goals and objectives of KKG program in Cluster I and 4 Blimbing, Malang to the needs and problems of increasing teachers' professionalism; (2) KKG input program viewed from the compatibility between the characteristics of the $\mathrm{KKG}$, work programs, and $\mathrm{KKG}$ organizational capabilities in achieving program objectives with KKG development standards; (3) KKG program implementation process viewed from the harmony of the tutor, member activity, infrastructure utilization, and KKG management performance with KKG development standards ; and (4) the effectiveness of KKG program for improving the teachers' professionalism and teachers of KKG members attitudes toward KKG program.

\section{Literature review \\ Related Studies}

Fakhruddin (2010) conducted a research entitled "Revitalization of Teacher Working Group to Develop Curriculum of Primary School Unit in Semarang". The results obtained from questionnaires distributed to 70 respondents indicated that most of the development mechanism of Teachers Working Group (KKG) management was determined through 
teachers' discussion with around 3 years of KKG periodization. The preparation of work program was set out by the board with annual and semester plans.

In improving teachers' self-development to be more professional, the majority (61.43\%) of the respondents conducted their meeting once a week, (32.86) respondents conducted their meeting once in 2 weeks and only a small proportion $(5.71 \%)$ conducted their meeting once in a month. The result also revealed that the ideal meeting is once a week $(72.86 \%)$. Some patterns of activities were carried out in different places according to the local conditions. The meeting was organized and led by a trained guide/facilitator. The meeting material was emphasized on practical elements and should be interactive.

As a way to enhance teachers' professional capabilities, its work program as undertaken in Semarang indicated the following facts: (1) programs related to professional development in the classroom was very useful $(80 \%)$. The usefulness appeared in the understanding of Unit Level Curriculum (SBC) by 67.14 percent, and the need to improve learning activities in the classroom by 32.86 percent, (2) as a forum for teachers in improving their performance, KKG was largely suitable by 61.43 percent yet was not implemented seriously, the learning process in KKG tended to be guide-centered and could not be accomplished in accordance with expectations. In addition, the teachers' level of discipline in following KKG has not shown significant development. It can be seen from teachers' level of lateness in attending KKG (3) The compliance of program application created by KKG met the expectations by 84.29 percent and the rest did not meet the expectation or not seriously implemented (4) the majority of KKG basic framework programs related to professional competence, pedagogical, social and personality was successfully implemented by 55.71 percent and 44.29 percent was not seriously implemented. The scores of KKG implementation indicated that KKG was not been implemented effectively. Therefore, they suggested that applicable programs should refer to the level of implementation by 70 percent and refer to a system by 30 percent, (5) Implementation of Unit Level Curriculum (SBC) in KKG activity has been preprogrammed, yet 57.14 percent indicated that the content was not in accordance with teachers' needs and demands.27.14 percent was programmed well, and 14.29 percent was not. SBC arrangement procedures met the requirement by 85.71 percent and in accordance with the orders even though 14.29 percent was not substantive (6) In order, the most frequent activities to be carried out included discussions, lectures, education and exercise. The priority of studies in these activities was dominated by the preparation of the curriculum, syllabus, teaching materials, and enrichment and remedial. Other forms included workshops, seminars and work workshops that have not received priority and have not been carried out routinely. Action research, papers, assessment tools and items analysis arrangement and such activities are usually handled by district and city educational ministry(UPTD), (7) Some of teachers' expectations associated with KKG are generally (a) allowing each teacher to share his/her experiences, giving support and feedback to each other in order to improve their knowledge, skills, attitude and adopting more innovative learning approach, especially those who have received education and training in higher ranks, (b) Dissemination of prominent or more experienced teachers at fellow teachers to improve the quality of teaching and learning outcomes to students, (c) a forum that is able to empower and assist teachers in performing their duties at schools in accordance with established standards, (d) changing work culture and develop teachers professionalism to ensure the quality of education. Government support in KKG empowerment was perceived low by of 68.57 percent. Government support is expected to 
be in the form of operational funds $(71.43 \%)$, by that reason of facilities and infrastructure condition in the school to carry out activities within the framework of curriculum development was inadequate.

Manap Somantri and Sa'adah (2011) in his research entitled "Revitalization of Teachers Working Group to Increase Primary School Teachers' Competencies and Professionalism in Seluma" found out that lesson study model for KKG empowerment was effective to improve teachers' ability to conduct learning through PAIKEM. This is supported by an increase in the quality of learning tools, learning process, activities and student learning outcomes. In detail, the results indicated that the empowerment of KKG by using lesson study model in Seluma could improve: (1) the quality of the learning process that focuses on student; (2) the teachers' awareness to be open and self-reflective through the implementation of open class in lesson study; (3) the interest of teachers, principals and school supervisors in particular to learn together; (4) harmony, cooperation between the schools supervisors with teachers or with principal in improving the quality of learning, particularly in the implementation of PAKEM; (5) the quality of supervisors coaching process to the teachers in partner schools; and (6) trainers' ability to conduct KKG needs analysis.

Results of Purnanda's (2011) research entitled "The Implementation of Teachers Working Group Function (KKG) in the State Elementary School (SDN) of Sungai Tarab, Tanah Datar." suggested that: (1) The functions of KKG seen from the aspect of educators' professional development was classified as "good" with the average value of 4.53; (2) The function of KKG seen from the aspect of problem-solving media was classified as "Good", indicating that KKG was fit enough as a vehicle for solving problems in improving the teachers' professionalism; (3) the implementation of KKG function viewed from the aspect of learning resources and cooperation among members was rated "Good", with an average value of 4.27; (4) The implementation of KKG function from the aspect of discovering and describing new ideas was also in the category of "Good", with an average value of 4.16 .

Wartoni's research (2013) entitled "Evaluation of Effectiveness of Teachers Working Group (KKG) On Quality Program" in Batang, Central Java resulted: (1) the condition of KKG in the district of Batang, Central Java was categorized as good, (2) the condition of facilities and infrastructure was categorized as good and supported the implementation of KKG in the district of Batang, Central Java, (3) organizational condition was categorized as good and programs went well for their intended purpose, (4) the role of teachers working group in the district of Batang, Central Java in promoting and developing teachers' professionalism was categorized as good, and (5) KKG product indicated that teachers' competence and students learning outcomes increased.

\section{The KKG as the Public Policy}

Public policy is a multidisciplinary science for it involves many disciplines such as politics, social, economy, and psychology. Policy study developed in the early 1970s mainly through Harold D. Laswell's work. The earliest definition of public policy was proposed by Harold Lasswell and Abraham Kaplan (Howlett and Ramesh, 1995: 2) defining public policy as "a program projected to particular goals, values, and practices ( a projected of goals, values, and practices) ". In line with this definition, George C. Edwards III and Ira Sharkansky (Suwitri, 2008: 10) define public policy as "a government action in the form of government programs for the achievement of goals or objectives," The two 
definitions indicated that the keywords of public policy include "goal", "values", and "practice." Public policy always has a purpose, such as government policies to develop KKG aims to improve primary school teachers' professionalism. The implementation is carried out by setting out standards ofKKG development as a guide for teachers in shaping and developing KKG.

Thomas R. Dye (Howlett and Ramesh, 2005: 2), defined public policy as "everything carried out by the government, what government did, why they do it, and what differences it makes. In the understanding that the "decision" also applied when the government decided "not to decide" or decide "not to take care" of an issue, this understanding also refers to the definitions of Thomas R. Dye (Tilaar and Nugroho, 2008: 185) stating that public policy is "everything that is carried out and not carried out by the government." in line with Dye's definition. Dye, George C. Edwards III and Ira Sharkansky (Suwitri, 2008: 9) also stated that public policy is: "What is stated and carried out, or not carried out by the government that can be specified in legislation or policy statement in the form of speeches and discourses expressed by political officials and government officials which is immediately followed up with programs and actions of the government." The two definitions equally agree that public policy also includes the terms of "the decision not to take any action". Meanwhile, Anderson (Subarsono, 2005: 2), public policy is a "policy set by agencies and government officials". In line with Laswell and Kaplan, David Easton (Subarsono, 2005: 2) defines public policy as "allocation of values to society," because each policy contains a set of values in it.

In the Regulation of the Ministry of Administrative and Bureaucratic Reform No. PER / 04/M.PAN/4/2007 on general guidelines for Formulation, Implementation, Performance Evaluation and Revision of Public Policy at Local and Central Governmental Institution explained that public policy is "a decision made by the government or government agencies to address specific issues, to perform certain activities or to achieve a particular purpose with respect to the interests and benefits of the people.'In the Regulation, public policy has two (2) forms of regulation codified formally and legally and statements of public officials in public. Such polcy can be in the form of Law, Government Regulation, Provincial Government Regulation, City Country Government Regulation, and Regent/Mayor Decision (Subarsono 2005:3). Based on this regulation, the statements of public officials is also part of public policy. This is understandable as public official is one of the policy actors who played a role in the implementation of the policy itself.

The KKG program is public policy whose the goal is as a media for Primary teachers' professional development and is formed by: (1) Law No. 20/2003 on National Education System; (2) Law No. 14/2005 on Teachers and Lecturers; (3) PP RI No.19/2005 on National Education Standards (SNP); (4) Permendiknas 22/2006 on Content Standards (SI); (5) Permendiknas 23/2006 on Graduation Standards (SKL); (6) Permendiknas 12/2007 on standards for School/madrasah; (7) Permendiknas 13/2007 on Principal standards; (8) Permendiknas 16/2007 on Academic qualification standards and Teacher Competency; (9) Permendiknas 19/2007 on Education Management Standards; (10) Permendiknas 20/2007 on Assessment Standards; and (11) Permendiknas 24/2007 on Infrastructure Standards. (MONE, 2008: 4). Policies can also be seen as a system. When a policy is seen as a system, it has its elements makers. According to Thomas R. Dye (Dunn, 2000: 110), there are three elements that make up the policy of the policy system, namely public policy, stakeholders, and policy environment. 


\section{Program evaluation}

Arikunto (2004: 7) explains that program evaluation is an attempt to determine the level of adherence to a policy carefully by knowing the effectiveness of each of its components. According to Rossi, Lipsey and Freeman (2007: 16), program evaluation is a systematic excavation of program effectiveness by using research methods. Patton (2008: 39) asserts that program evaluation is a systematic data collection activity about program activity, characteristics, and outcomes, and then they are used to make decisions about the program, improving or increasing the effectiveness of the program more informed decisions about the next program and increase understanding of the program. According to Sudjana (2006: 21), program evaluation is systematic activities to collect, process, analyze and present the data as input to decision-making.

Posavac and Carey (1983: 5) considered program evaluation as a collection of method, skills, sensitivity required to determine whether a community service program (human services) needed and used, whether a program can meet the needs adequately, whether a program is implemented according to plan, and whether a program is actually able to help people in need. Harris (Sudjana, 18-19) stated that program evaluation is systematic setting process about value, purpose, effectiveness, or compatibility of something in accordance with criteria and goals set earlier. Decision setting process is based on a careful comparison on the observed data by using certain standards that have been standardized. According to Alkin (Sudjana, 20), program evaluation is a process related to the preparation of various decision areas through the selection of appropriate information, data collection and analysis, and reporting that is useful for decision makers in determining the various alternative options to determine decisions. Isaac and Michael (1981: 6) argued that a program should be terminated with evaluation. There are three (3) stages series program evaluation, namely (1) stating question and specifying information to be obtained, (2) searching for relevant data to conduct research and (3) providing information needed by the decision maker to determine whether a program is continued, amended or stopped.

Based on some definitions about program evaluation, it can be concluded that program evaluation is an activity carried out systematically to provide an assessment of the success or effectiveness of a program based on the criteria or goals that have been set, further followed by a decision on the program.

\section{Context, Input, Process, Program(CIPP) Program Evaluation Models}

CIPP Evaluation model basically serves four kinds of decisions (Stufflebeam and Shinkield, 1986: 330). First, evaluation context for planning decisions, that the decision is to set a goal to be achieved (to Determine objectives). Second, evaluation input to decision formation (structuring decision), that this decision is to design instructional design (to design instruct-tion) to achieve the objectives that have been derived from the planning decision. Third, evaluation process for decision implementation (implement ing decision), that the decision is to implement or improve learning implementation (to use or improve instruction). Fourth, product evaluation for playback decision (recycling decision), that the decision is intended to judge a product, output, or outcome to determine whether a program is continued, continued with modifications, or discontinued based on the existing criteria. 
According to Kaufman and Thomas (1980: 114-115), the essence of CIPP evaluation model can be seen from the definition of evaluation stated by Stufflebeam, that evaluation is the process of delineating, obtaining, providing valuable information to take a decision alter-natives. Delineating refers to the range of information highly required for decision making. The highly needed data and information are obtained through dialogue between the evaluator team and decision makers. The two parties together hold a discussion to ensure that the data obtained is of critical data; compile plan how to obtain such data; set goals, and identify data that is considered as valuable information. Obtaining refers to the process of collecting actual data, which is data that really exists and happens in the field, and how the data is analyzed. In this context, the emphasis is more on the collection and preparation of information or data that is really needed for decision making. In this regard, a team of evaluators must cooperate and participate actively with a group of people who are considered as a source of information. Providing refers to the effort to provide information or data that can add value (usefulness) for decision making. The activities include providing synthesis of some information or data obtained and preparation of tables and charts that can help decision-makers work. While evaluator team can provide initial interpretation of the data obtained, the final interpretation or meaning is the meaning derived from the results of cooperation between decision makers and evaluator team. The decision set is also a decision which determines the result of collaboration between evaluator team and decision makers.

Popham (1975: 33-37) explains that the CIPP evaluation has two orientation purposes; for the benefit of decision-making or formative oriented, and for accountability or summative oriented. Each component in CIPP has usefulness characteristics by the two types of orientation. In formative orientation, evaluation context guides toward goals elections and priorities setting; input evaluation guides to program strategy selection to specify the design of the program; guiding the evaluation process in the implementation of activities; and the product evaluation guide whether activities should be terminated, continued, modified, or assigned. While on the orientation of summative evaluation context as a record of the purposes and principles of the election; evaluation input as a record of the election strategy and the design and rationale of the election; evaluation process as a record of the process of implementation or actualization; and evaluation of the product as a record of achievement and decisions for improvement.

According to Nevo (1986: xvi), the focus of evaluation with a CIPP models aimed at assessment of the benefits of interest, the quality of the plan, the implementation process, and improved outcomes. Referring to the opinion of Nevo, then the orientation of the CIPP evaluation can be categorized as follows. First, the context oriented evaluation to assess the benefits of the program objectives. Second, the evaluation of inputs for assessing the quality of the program plan. Third, the evaluation process to assess the implementation process or program implementation. Fourth, product evaluation to assess the outcomes implications on improving outcomes.

Related to KKG program evaluation, it can be concluded that $\mathrm{KKG}$ evaluation program is evaluation of context component with orientation on goals assessment and the relevance to the context that surround; evaluation of input with orientation on assessment of quality of KKG program design; evaluation of process component with orientation on assessment of KKG program implementation process; and evaluation of product component with 
orientation on assessment of KKG program outcomes in the form of knowledge, skills, and attitudes.

\section{Teachers Working Group (KKG) \\ a. Understanding KKG}

$\mathrm{KKG}$ is a forum of professional activities for elementary/islamic school teachers in cluster or sub-district level consisting of several teachers from several schools (MONE, 2008: 6). KKG can be used to communicate, exchange ideas and share experiences, carry out a variety of demonstration, attractions and simulations in learning. Education Quality Assurance Institutions (LPMP) provides several definitions of KKG, namely: (1) A forum for professional teachers (class/subjects) in Regency/City /District/studio / school cluster, with the principle of a reflection of activities, by and for teachers of all schools; (2) An independent non-structural organization, family based, non-hierarchical relationships with other institutions, a forum of teacher professional activities primarily for teachers in charge as classroom teachers and subject teachers.

\section{b. Objectives and Benefits of KKG}

KKG aims to: (1) Expand teachers' horizons and knowledge in various ways, particularly on the mastery of the substance of learning materials, syllabus, preparation of learning materials, learning strategies, teaching methods, maximize the use of facilities/infrastructure to learn, utilize learning resources, etc. ; (2) Provide opportunities for members of working groups or working meetings to share experiences and provide mutual support and feedback; (3) Enhance knowledge and skills, as well as adopt a reform approach in a more professional learning for participants of working groups or working meetings; (4) empower and assist members of the working group in conducting learning tasks in school; (5) change work culture of working group members (improvement of knowledge, competence and performance) and develop teachers professionalism through professionalism development activities in KKG level; (6) Improve the quality of education and learning reflected in improved students learning outcomes; and (7) Improve teachers competence of through activities in KKG. (MONE, 2008: 5). 6. Framework of thinking Evaluation of teachers' professionalism Development Policies through KKG program in this study used CIPP model to evaluate four components, they are: context, input, process, and product. Context valuation is used for evaluating $\mathrm{KKG}$ objectives, needs and problems of teachers in improving professionalism through $\mathrm{KKG}$, and resources readiness, both personnel and funding. Evaluation was carried out by studying the documentation of policy and data related to the object of evaluation, observation, and interviews with informants related. The result of the evaluation is in the form of context effectiveness level as decision making of KKG program planning policy (planning decision). Input evaluation is intended to evaluate the characteristics of teachers, curriculum and teaching materials of trainings programmed in $\mathrm{KKG}$, quality of speaker or tutor, training infrastructure and capability of KKG administrator in managing KKG program. The evaluation was carried out through documentation, observation, and interviews with teachers and administrators informants. The results of the evaluation is the level of input effectiveness functions as structuring policy decision making of KKG program (Structuring Decision), which is a policy decision to design the training or learning (to design instruction) as an effort to achieve the goals derived from planning decision. Process evaluation is intended to evaluate the facilitator performance, the teacher's activities in various training activities organized by $\mathrm{KKG}$, use of media and learning resources in training, and performance evaluation of the board of KKG. The data were also collected by documentation, 
observation, and interviews. The results of the evaluation is the level of process effectiveness functions as decision implementation (Implementing Decision), that the decision is intended to continue the implementation of training programs or improve the implementation of a training or learning (to use or improve instruction). Product evaluation is intended to evaluate changes in knowledge and skills, and teachers' attitudes toward KKG program after attending various trainings conducted by KKG. Data were obtained with documentation, observation, and interviews. The results of the evaluation is in the form of level of product effectiveness functions as recycling policy decision making (recycling decision), namely weighing program (to judge product, outputs, or outcomes) for the next determination whether a program is continued, continued with modifications, or terminated based on the existing criteria.

Based on the level of context, input, process, and product effectiveness of KKG, the level of KKG program effectiveness in both studied clusters can be set. Recommendations can be then proposed to policymakers of KKG development standards, the Ministry of Education and Culture and the parties involved in the implementation of KKG policy.

\section{Research method}

This research was a study to evaluate the program policy of teacher working group (KKG). The research method was qualitative. The model assessment used an evaluation model Context, Input, Process, and Product (CIPP) developed Stufflebeam. The objects of research were cluster 1 and cluster 4 Blimbing, Malang, East Java, Indonesia, in January-April 2016. Sources of data were officials and some members of KKG teachers and administrators in both groups. The research instruments were observation, interview, and documentation. Analysis of data used procedures Yin (2011) with five stages, namely: a compilation of data, disassembling, rearrangements, interpretations, and conclusions.

\section{Results and discussion \\ The Effectiveness of Context Component}

Viewed from the relevance between the goals and objectives of the program teacher working group (KKG) in Cluster I and Cluster 4 Districts Blimbing Malang Regency to the needs and problems increased professionalism of teachers, KKG context in both clusters were sufficiently effective to achieve program objectives. The purpose of KKG cluster 1 was to improve the professionalism of teachers in learning. While the teachers' needs and problems were drafting midterms, final exams and school exam, lesson plan based K-13, IT use, and writing scientific paper. The teachers' needs and problems were reflected in the KKG program despite the increased ability of the teacher to write scientific program not yet been implemented because of lack of funds. Therefore KKG context component group 1 was quite effective.

Cluster 4 essentially had the same purpose as cluster 1 . While the teachers' need and problem were as follows: (1) drafting lesson plan K-13; (2) using innovative methods in teaching; (3) drafting midterm; (4) exploring the predicted national exam; (5) discussing the national exam; (6) holding the workshop of school health unit (UKS) management; and (7) holding the workshop of thematic learning. KKG program reflected the needs. Therefore there was relevance between the needs and KKG program. But there was still need for teachers who had not been accommodated in the program, namely the need for skills in using IT in learning and writing scientific writing, especially action research. In 
addition, there was a need that did not include an increase in the professionalism of teachers in learning, the workshop of school health unit management. Thus there was still confusion in the preparation of work programs at KKG cluster 4. Another program that was not defined by the results of a training needs analysis was assisting the implementation of K-13. This program was a package of government assistance to do. KKG was believed to carry them out with consideration to meet the needs of teachers in preparing lesson plans K-13 and simulated learning with innovative methods. These indicated that the context component of KKG cluster 1 was more effective than cluster 4. Cluster 1 had a purpose, the needs of teachers, and work programs more relevant than cluster 4. If it was based on the development standard (SP) of KKG / MGMP (MONE, 2008: 7) that the KKG program cluster 1 and cluster 4 still were short-term programs (an annual program), while the medium-term program and a long-term, as desired SPKKG / MGMPs not encountered. This was due to the KKG development standards were not yet fully socialized to KKG cluster 1 and cluster 4 .

Viewed from work program, the program was written in the calendar of activities in a school year. The formulation of the vision and mission as well as an explicit goal was not found for cluster 1 and for cluster 4 . This was clearly not in line with the standards program of SPKKG / MGMP (MONE, 2008: 7) which states that: "Preparation of KKG program started from preparing the vision, mission, goals, until the calendar of events."

The results of the evaluation component KKG context of cluster 1 and cluster 4 showed that KKG board invited representatives of teachers in the preparation of work programs; namely the coordinator class and subject areas conveyed the needs of teachers who needed to be accommodated in the work program. In the meeting, program of work was made in the next school year under the guidance of the school superintendent and known Chairman of the Working Group of local principal. The program formulation mechanism or less in line with the standards program SPKKG (MONE, 2008: 16) that describes the design of programs that KKG should be done: (1) a SWOT analysis; (2) the results of SWOT analysis are discussed with the member; (3) the preparation of the initial draft by special teams; (4) discussion program by the board, members, principals, and supervisors; (5) Revision of the program by a special team; (6) a draft final program until approved by the Head of Education Department of Malang or officer authorized to represent.

Viewed from the legality of the program, cluster 1 and cluster 4 signed by the Chairman of KKG and known Chairman of the Working Group local Principal (SD), not yet approved by the Head of Education regencies / cities as preferred SPKKG / MGMP. The working program of KKG cluster 1 and cluster 4 were not classified into routine programs or development programs as preferred SPKKG / MGMP. In the standard program development, program routine at least consists of: (a) Discussion of learning problems; (B) The preparation of the syllabus, the semester program, and plan learning program plan; (C) Analysis of the curriculum; (D) Preparation of an evaluation instrument of learning; and (e) Discussion of the material as well as consolidation of the national exam.KKG program cluster 1 could be classified into routine programs because there was a workshop program with the use of IT in learning, which could be incorporated into development programs. The development programs could be selected at least three of the following activities: (A) Research; (B) The Essay Writing; (C) Seminars, workshops, colloquia (exposure to research results), and panel discussions; (D) KKG tiered (tiered education and training); (E) Issuance of the KKG journal; (F) Preparation of KKG 
website; (G) KKG Forum province; (H) Competition teacher performance; (I) Peer Coaching (training fellow teachers using ICT media); (J) Lesson Study (cooperation among teachers to solve learning problems); (K) Professional Learning Community (community-learning professionals); (L) TIPD (Teachers International Professional Development) / MGMPs international cooperation; (M) Global Gateway (cross-country partnerships)

Viewed from the standards organizations; by KKG Development Standards; KKG organization comprised of officers, members, SK endorsement by the District Education Office / City, and has AD / ART. KKG Board consists of: Chairman, Secretary, Treasurer, and Fields, elected by the members based AD / ART (MONE, 2008: 8). Based on these standards, cluster 1 and cluster 4 had not been able to demonstrate: (1) SK endorsement by the District Education Office / City; and (2) AD / ART. KKG in the management structure of cluster 4, in addition to the daily board there was only Public Relations 1 and 2, while other fields did not exist. KKG infrastructure should be minimal provided that: (1) Room / Building for KKG; (2) Computer; (3) teaching aids; (4) OHP / LCD projectors; and (5) Telephone and Facsimile. KKG cluster 1 and cluster 4 had owned all the means although for the room, telephone and fax, and teaching aids ownership status still belongs to the main elementary school.

Interviews showed that the budget of KKG cluster 1 and cluster 4 were not enough to finance activities of the entire program. Sources of funding were: (1) membership fees / school; and (2) blockgrand of government. Other sources, such as donors, production unit, the result of cooperation, community, and sponsors are not binding and valid as described in the standard development of KKG which had not been found as a source of funds in KKG cluster 1 . In terms of training evaluation, evaluation model that had been done was still far away from Development standards of KKG. The evaluation included: (1) the evaluation of the event; (2) evaluation of participants' responses; (3) evaluation of the participants' understanding; and (4) evaluation of program benefits for participants. The entire evaluation was conducted by monev team and committee. While training evaluation responsibilities were held by each tutor.

\section{The Effectiveness of Input Component}

The findings showed that the interest of teachers to the KKG program cluster 1 and cluster 4 as well as the teachers' needs for additional knowledge and skills in the management of learning, training programs, and capabilities of tutors and administrators of KKG in both clusters could be noted that the input component of KKG in cluster 1 was quite effective, while cluster 4 was less effective. The teachers of cluster 1 had a high interest to follow KKG. They suggested the kind of knowledge and skills need to be improved in the management of learning. Then, KKG Board responded with a variety of training programs. Although officials felt less competent, but they were ready to empower internal and external tutors who were competent.

The teachers of cluster 4 had a high interest in the KKG program, increased knowledge and skills of teachers in teaching, training programs relatively in accordance with the needs of teachers, administrators of KKG cluster 4 who were capable, but on the other hand the majority of tutors were less competent. It affected KKG input component cluster 4 Blimbing district of Malang less effective. When it was compared with KKG development standards, it still had some shortcomings, as follows: Standard management 
explained that: (1) Implementation of each KKG program conducted by a committee headed by a chairman in charge under the KKG decree; (2) The implementation of each program based on the Terms of Reference (TOR) prepared by the KKG board; (3) The committee made a proposal that includes: planning, execution, financing, and reporting activities; (4) The Board monitors and evaluates the activities. In the cluster $1 \mathrm{KKG}$ implementation of activities managed directly by the board. KAK was not found there, only the schedule work program. The proposal made by the board on activities. In the cluster $4 \mathrm{KKG}$, almost all training programs were administered directly by the board, except for the implementation of mentoring training program K-13. The training program that was actually not a pure KKG program. Cluster 1 had not conducted all programs of $\mathrm{KKG}$, such as training programs using new teaching methods, such as CTL, cooperative STAD, and Jigsaw. When the KKG board was confirmed, these activities had not programmed because of limited financial resources such as funding for external tutor. In addition, other supporting facilities were not yet available, such as libraries, science laboratories, and micro teaching laboratory.

Viewed from academic qualification of tutors, both tutors internal and external of KKG cluster 1, it met the requirements set forth in the standards development KKG, namely: Educators who became KKG/ MGMP coaches had to have the criteria as follows: (1) they had an academic qualification at least $\mathrm{S} 1 ;(2)$ they had a teaching experience at least 10 years; (3) they had expertise relevant to the submitted materials (HR Standards Development of KKG / MGMP item 1). Tutors at KKG cluster 4 mostly internal tutors and assessed by the board did not have expertise relevant to the topic. They had not been certified as a tutor even though on average they had had over 10 years of teaching experience and $\mathrm{S} 1$ academic qualification.

Viewed from the mechanism of determining the needs of tutors; permanent or temporary; in cluster 1 and cluster 4 were still not in accordance with the standards development of KKG. Operational procedures of temporary tutor temporary was determined based on KKG standards development as follows:(1) The Board identified the competencies that would be developed; (2) The Board identified a resource that was in accordance with the requirements; (3) The Board contacted the source accompanied by a letter of application and proposal activities; and (4) Asked the speaker to prepare materials and media. While the operational procedures of determining the permanent instructor / teacher-core / companion followed these steps: (1) The Board identified the competencies that would be developed; (2) The officials identified the instructor / teacher-core / companion as necessary; (3) The Board appointed an instructor / teacher-core / chaperone accompanied by a letter of assignment and proposal activities; (4) Asked the instructor / teacher-core / companion to prepare materials and media. (MONE, 2008: 14).

\section{The Effectiveness of Process Components}

The findings showed that the compatibility between the performance of the tutor, member activity, infrastructure utilization, and performance of KKG administrators were quite effective for cluster 1 and cluster 4 . The four indicators of KKG program implementation process supported that assessment. Tutor at the KKG training cluster 1 and cluster 4 showed a good performance. They were able to: (1) master the material; (2) manage the discussion of the material; (3) link the training materials with the needs and problems of improving the professionalism of teachers; (4) provide motivation to learn to teachers; (5) use the appropriate learning media; (6) select and use effective learning methods; (7) 
manage the training time; (8) use Indonesian correctly; (9) being kind to the teacher; (10) give and answer questions about the training materials; and (11) achieve the training objectives. Activities of teachers in some training showed their concern were very high. They were actively involved in the training process except for teachers who would get retired. Cooperation among teachers in training was quite harmonious. This was evidenced by the working group in each training. For example, in cluster 4, they simulated the K-13 learning in assisting the implementation of K-13 in all classes. In addition, teachers had high discipline and order in the following training activities. Teaching aids for training teachers considered quite varied. The media could be fully utilized in training such as projectors, computers, internet (website) and stationery supplies. Learning resources were quite varied such as textbooks, modules, internet, and resources. However, cluster 4 did not use teaching aids such as internet and video.

Viewed from the management structure of KKG, the ability of the KKG board provided services to teachers, the ability of the KKG board responded to problems faced by teachers in implementing the tasks profession, harmonious cooperation among administrators, the interaction between administrators, teachers, and coaches, as well as the ability of administrators to manage KKG program, then performance of administrators could range quite well. Nevertheless there were still some shortcomings when it was based on KKG standards development, among others: (1) the ability of the board to provide services and respond to the problems of teachers still slow because they also had a primary obligation as a teacher and must ask for approval of KKKS in the realization of any work program KKG Cluster 4 and limited funds; (2) the board was still not able to manage the organization in a professional manner according to standards development of KKG, a good standard of preparation of the work program, determining the sources of temporary external and internal tutor, provision of infrastructure, program management, operational finance, nor with the operational standards of quality assurance.

In the standard development of KKG (MONE, 2008: 14) explained that the operational procedures of determining a temporary KKG resource followed these steps: (1) The Board of KKG identified the competencies that would be developed; (2) The Board identified a resource that was in accordance with the requirements; (3) The Board contacted the source which was accompanied by a letter of application and proposal activities; and (4) Asked the speaker to prepare materials and media. While the operational procedures of determining the instructor / teacher core / companion (permanent) followed these steps: (1) The Board identified the competencies that would be developed; (2) The officials identified the instructor / teacher-core / companion as necessary; (3) The Board appointed an instructor / teacher-core / chaperone accompanied by a letter of assignment and proposal activities; (4) Asked the instructor / teacher-core / companion to prepare materials and teaching aids. Building infrastructure mechanism to hold KKG were: (1) The Board conducted annual preparation (early years); (2) The Board determined or school buildings to be used for KKG; (3) The Board filed a loan application to the Principal and Head of the Education Department; (4) Principal and Head of the Education Department issued a building use permit; (5) The Board received permission and then the board could see the building. (MONE, 2008: 17).

In the provision of KKG also determined the mechanism that should be adhered to board of KKG, namely: (1) The executive committee identified activities of KKG program objectives; (2) The Committee determined the necessary means; (3) The Committee 
should examine the availability of the necessary means; (4) The Chairman and Committee decided means to be purchased; (5) The Chairman and the Committee made a purchase; (6) Members used the means that had been purchased. (MONE, 2008: 18).

\section{The effectiveness of Product Components}

Viewed from the benefits of KKG program for the improvement of teacher professionalism and positive attitude of teachers towards KKG program; the implementation of KKG program was quite effective to both cluster 1 and cluster 4 . Teachers of cluster 1 had a lot of benefits especially the use of IT in learning, K-13 lesson plan, material of teaching, and in increasing the number of credits (PAK) of functional teacher position. Moreover, they were very enthusiastic towards the KKG program. They strongly supported the program. Only a few teachers who would get retired were less supportive to $\mathrm{KKG}$ program.

Teachers of cluster 4 got a lot of benefits especially as follows: (1) improve the professionalism; (2) make lesson plans and teaching-material based curriculum2013; (3) help teachers to choose and use teaching aids; (4) make KKG as a forum for teachers to share their knowledge and experience. Unfortunately, some of the teachers' concerns in cluster 4 could not be programmed, including the use of IT in the learning workshop, PAK workshop, and scientific papers workshop; especially action research.

\section{Conclusion}

This Research concluded that: (1) viewed from the relevance between the goals and objectives of the program teacher working group (KKG) in Cluster I and Cluster 4 Districts of Blimbing Malang to the needs and problems increased professionalism of teachers, KKG context in both clusters were sufficiently effective to achieve program objectives. KKG context component of group 1 was more effective than cluster 4 . Cluster 1 had a purpose, the needs of teachers, and work programs more relevant than cluster 4 , (2) viewed from the interests of teachers, teachers' needs, teachers' skills, training programs, tutors' capabilities, and administrators of KKG, cluster 1 had component inputs more effectively than cluster 4 .In cluster 1 , the teachers had a high interest to follow KKG. They suggested the improvement of knowledge and skill in the management of learning. Then, the administrator of KKG responded to make programs as their suggestion although administrators felt that they were less competent. But they were ready to empower internal and external tutors who were competent. On the other hand, in cluster 4, the majority of tutors were less competent; therefore the input component was less effective, (3) viewed from the performance of the tutor, member activity, infrastructure utilization, and performance of KKG administrator; it showed that the implementation of KKG Program was quite effective to both cluster 1 and cluster 4, (4) viewed from the benefits of KKG program for the improvement of teacher professionalism and positive attitude of teachers towards KKG program; the implementation of KKG program was quite effective to both cluster 1 and cluster 4 . Teachers of cluster 1 had a lot of benefits especially the use of IT in learning, K-13 lesson plan, material of teaching, and in increasing the number of credits (PAK) of functional teacher position. Moreover, they were very enthusiastic towards the KKG program. They strongly supported the program. Only a few teachers who would get retired were less supportive to KKG program. Teachers of cluster 4 got a lot of benefits especially as follows: (1) improve professionalism; (2) make lesson plans and teaching-material based curriculum2013; (3) help teachers to choose and use teaching aids; (4) make KKG as a forum for teachers to 
share their knowledge and experience. Unfortunately, some of the teachers' concerns in cluster 4 could not be programmed, including the use of IT in the learning workshop, PAK workshop, and scientific papers workshop; especially action research. Both cluster 1 and cluster 4 had effective product components, so KKG program could be continued with various refinements as well as referred to the standard of $\mathrm{KKG}$ development.

\section{References}

Abdullah, 2004. Professional Development for SD Teachers Through School Cluster, Teachers in Indonesia. Their Education, Training and Struggle Ince Colonial Era untuk Reformation Era. Directorate General of Primary and Secondary Education. Jakarta: Ministry of National Education of The Republic of Indonesia.

Agung, Iskandar and Yufridawati. 2013. Pembangunan Pola Kerja Harmonisdan Sinergis antara Guru, Kepala Sekolah, dan Pengawas. Bestari Buana Murni: Jakarta.

Amiruddin.TT."Pengembangan Profesionalisme Guru Sekolah Dasar Daerah

Terpencil melalui Dana Blockgrant di Provinsi Nanggro Aceh Darussalam”. Tidak Diterbitkan.

Anderson, Scarvia B., Ball, Samuel, dan Murphy, Richard T. 2000. Encyclopedia of Educational Evaluation. California: Jossey-Bass, Inc., Publisher.

Arikunto, Suharsimi dan Jabar, Cepi S. 2004. Evaluasi Program Pendidikan, Pedoman Teoretis Praktis bagi Praktisi Pendidikan, Jakarta: Bumi Aksara, 2004.

Bloom, Benjamin S., Hastings, Thomas, dan Madaus, George F. 1971. Handbook on Formative and Summative Evaluation of Student Learning, New York: McGrawhill Book Company.

Boulmetis, John dan Dutwin, Phyllis. 2005. The ABCs Of Evaluation. San Francisco: Jossey-Bass Inc. Publishers.

Brameld, T. 1966. Philosophy of Education in Cultural Perspective. New York: Holt, Rinehart and Winston, Inc.

Bronte-Tinkew, J., Horowitz, A., Redd, Z., dan Valladares, S. 2007. A Glossary of Research Terms for Out-of-School Time Program Practitioners, Research-to-Resulth. Washington D.C.: Child Trends.

Cangelosi, James C. 1991. Evaluating Classroom Instruction. New York: Longman Publishing Group.

Creswell, John W. 1994. Research Design: Qualitative \& quantitativee approach. Thousand Oaks, London, New Delhi: Sage.

Cohen, J. \& Weimann, G. 2000, "Cultivation Revisited: Some Genres Have Some Effects on Some Viewers". Communication Reports, 13 (2).

Combs, H.P. and Manzoor, A. 1975. Educational For Rural Deveolpment: Case Study For Planners. New York: Praegar Publishers.

Departemen Pendidikan Nasional. 2007. Pedoman Evaluasi Dampak Pendidikan Nonformal. Jakarta: Ditjen PMPTK, Departemen Pendidikan Nasional.

Dirjen PMPTK. 2010. Pedoman Pengelolaan Pengembangan Keprofesionalan Berkelanjutan (PKB). Jakarta: Depdiknas.

Djaali and Muljono, Pudji. 2004. Pengukuran dalam Bidang Pendidikan, Jakarta: Program Pascasarjana Universitas Negeri Jakarta.

Dunn, William, N. 2003, Analisis Kebijakan Publik. Yogyakarta: PT. Hanindita Graya Widya.

Dunn, William, N. 2007. Public Policy Analysis: An Introduction, $4^{\text {th }}$ edition, New Jersey: Pearson Prentice Hall. 
Edward III, George C., 1980, Implementing Public Policy. Washington DC.: Congressional Quarterly Press.

Faisal, S. 2002. "Profesi dan Bidang Studi Pendidikan Luar Sekolah (PLS)." Tesis Program Pascasarjana Universitas Negeri Malang (UM): Malang. Tidak Diterbitkan.

Fakhruddin. 2010. "Revitalisasi Kelompok Kerja Guru Dalam Mengembangkan Kurikulum Satuan Pendidikan Sekolah Dasar Di Kota Semarang”. Laporan Penelitian (tidak diterbitkan). Fakultas Ilmu Pendidikan Universitas Negeri Semarang.

Fitzpatrick, Jody L., Sanders, James R. dan Worthen, Blaine R. 2004. Program Evaluation, Alternative Approaches and Practical Guidlines. New York: Pearson Education, Inc.

Flagg, Barbara N. 1990. Formative Evaluation for Educational Technologies. New Jersey: Lawrence Erlbaum Associates Publisher.

Gomby, D.S. dan Larson, C.S. 1992. "Evaluation of School-linked Services," dalam The Future of Children: School Linked Services ed. R. Behrmann. California: Center for the Future of children and David and Lucile Packard Foundation.

Gronlund, Normand E. 1985. Measurement and Evaluation in Teaching, New York: McMillan Publishing Company.

Indrawati. 2013. Peningkatan Profesionalisme Guru dan Upaya Pengembangannya Melaui CPD/PKB. Bandung: Forum Kreativitas dan Karya Inovasi PTK IPA

Isaac, Stephen dan Michael, William B. 1981, Handbook in Research and Evaluation, For Education and the Behavioral Science. California: Edits Publishers.

Jalal, Fasli dan Supriadi, D. (Ed). 2001. Reformasi pendidikan dalam Konteks Otonomi Daerah. Yogyakarta: Adicita Karya Nusa.

Jalal, Fasli. 2007. Hand-out Rembug Nasional. Ditjen PMPTK, Depdiknas.

Jarvis, Peter 1983, Adult and Conditionong Education: Theory and Practice. Croom Helm, Ltd.

Kaufman, Roger dan Thomas, Susan 1980. Evaluation Without Fear, New York: New Viepoint.

Koster, Wayan 2006. Memperjuangkan Nasib Guru dan Dosen. Jakarta: tanpa penerbit.

Mathis, R.L. dan Jackson, John H. 2002. Manajemen Sumber Daya Manusia. Alih Bahasa Thomson. Jakarta: Salemba Empat.

Mawardi, Fanny. 2006. "Efektivitas Program Pendidikan dan Pelatihan Pegawai Pemerintah DKI Jakarta dalam Rangka Pengembangan Sumberdaya Manusia.” Disertasi. Universitas Negeri Jakarta.

Nasution, S. (1988). Metode Peneltian Naturalistik Kualitatif. Bandung: Tarsito

Nevo, David. 1986. "Evaluation: What Is It?" dalam Program Evaluation; A Practitioner's Guide for Trainers and Educatiors, ed. Brinkerhoff. Boston: KluwerNijhoff Publishing.

Niachooff, R.O. 1977. Non Formal Education and Rural Poor. East Lansing: M.S.U Institute For International Studies

Owen, John M. 1993. Program Evaluation, Form and Approaches. New South Wales: Allen and Unwin Pty. Ltd.

Patton, Michael Q. 2008. Utilization-focused Evaluation, California: Sage Publication. Peraturan Menteri Pendayagunaan Aparatur Negara Nomor PER/04/M.PAN/4/ 2007 tentang Pedoman Umum Formulasi, Implementasi, Evaluasi Kinerja, dan Revisi Kebijakan Publik di Lingkungan Lembaga Pemerintah Pusat dan Daerah.

Peraturan Pemerintah Nomor 19 tahun 2006 tentang Standar Nasional Pendidikan.

Peraturan Pemerintah Nomor 73 Tahun 1991 tentang Pendidikan Luar Sekolah. 
Popham, William J. 1975. Educational Evaluation. New Jersy: Prentice-Hall. Inc.

Posavac, Emil J. dan Carey, Raymond G. 1983. Program Evaluation, Methods and Case Studies (New Jersey:Prentice-Hall, Inc.

Preskill, Hallie dan Rust-Eft, Darlene 2005. Building Evaluation Capacity, 72 Activities for Teaching and Training, California: Sage Publication.

Purnanda, Aan. 2013. "Pelaksanaan Fungsi Kelompok Kerja Guru (KKG) di Sekolah Dasar Negeri (SDN) Kecamatan Sungai Tarab Kabupaten Tanah Datar." Jurnal Administrasi Pendidikan Volume 1 Nomor 1 Oktober 2013.

Purwanto and Suparman. 1999. Evaluasi program DIKLAT. Jakarta: STIA-LAN Press.

Roger, Glyn dan Badham, Linda. 1992. Evaluation in Schools, Getting Started on Training and Implementation. London: Routledge.

Rohmzd, Z. 1994. Eksisitensi Pendidikan Luar Sekolah. Surabaya: IKIP Surabaya.

Rossi, Petter, Lipsey, Mark W., dan Freeman, Howard W. 2007. Evaluation, A Systematic Approach. London: Sage Publication.

Sanusi, Ahmad, dkk. 1991. Studi Pengembangan Model Kependidikan Profesional Tenaga Kependidikan. Departemen Pendidikan dan Kebudayaan, Bandung: Institut Keguruan dan Ilmu Pendidikan

Somantri, Manap \& Ridwan, Sa'adah. 2011. "Revitalisasi Kelompok Kerja Guru Guna Meningkatkan Kompetensi Dan Profesionalisme Guru Sd/Mi Di Kabupaten Seluma". Jurnal Kependidikan Triadik, April, Volume 14, No.1

Standar Pengembangan Kelompok Kerja Guru (KKG) dan Musyawarah Guru Mata Pelajaran (MGMP) 2008, Jakarta, Direktorat Profesi Pendidik, Direktorat Jenderal Peningkatan Mutu Pendidik dan Tenaga Kependidikan, Departemen Pendidikan Nasional Republik Indonesia.

Stufflebeam, Daniel and Shinkfield, Anthony J. 1986. Systematic Evaluation, A SelfInstructional Guide to Theory and Practice. Boston: Kluwer-Nijhoff Publishing.

Sudjana, Djudju. 1993. Strategi Pembelajaran dalam Pendidikan Luar Sekolah. Bandung: Nusantara Press. , 2006. Evaluasi Program Pendidikan Luar Sekolah. Bandung: Program

Pascasarjana Universitas Pendidikan Indonesia dan Remaja Rosdakarya.

Tayibnapis, Farida Y. 2000. Evaluasi Program. Jakarta: Rineka Cipta. 